\title{
ANALISIS PENGARUH INTEGRATIVE LEADERSHIP TERHADAP ORGANIZATIONAL JUSTICE, EMPLOYEE ENGAGEMENT DAN ORGANIZATIONAL CITIZENSHIP BEHAVIOR
}

\author{
Veronika Agustini Srimulyani \\ Dosen Prodi Manajemen, Fakultas Ekonomi, Unika Widya Mandala Madiun
}

E-mail vero@staff.widyamandala.ac.id

\begin{abstract}
Organizations have long been interested in how employees think and feel his work and what causes employees are willing to dedicate themselves to the organization. The researchers found a variable motivational leadership style that leads to the formation of positive attitudes of the officials who in turn can improve employee job performance. The objective of this research are to study the effect integrative leadership on organizational justice, employee engagement, and organizational citizenship behavior (OCB), with teachers at SMA/SMK/MAN/MAS di kota Madiun as respondents. This research used the quantitative approach with the survey method. The samples of this research were 409 teachers, selected non-randomly. The data were obtained by distributing questionnaires and analyzed by using the descriptive statistics and path analysis in inferential statistics. The results of the research can be concluded that: integrative leadership has a positive significant effect on organizational justice; integrative leadership significant positive effect on employee engagement; integrative leadership significant positive effect on employee engagement on OCB.
\end{abstract}

Key Word: integrative leadership, organizational justice, employee engagement, organizational citizenship behavior.

\section{PENDAHULUAN}

Beberapa konsep dalam perilaku organisasional yang terus mengalami perkembangan hingga saat ini adalah pendekatan kepemimpinan, keadilan organisasional (organizational justice) dan keterikatan pegawai pada organisasi. Servant leadership yang dapat disebut sebagai integrative leadership yaitu pendekatan kepemimpinan yang berupaya mencari jalan tengah atau semacam terobosan dengan cara mengintegrasikan sejumlah keunggulan dari model-model kepemimpinan yang ada dengan mengkolaborasikan antara orientasi pada karakter pemimpin, manusia, tugas dan proses; sehingga diyakini mampu mengikat, mengharmonisasi, meningkatkan perilaku extra-role atau organizational citizenship behavior (OCB), membangun kesehatan mental yang baik, menurunkan tingkat stres, dan berbagai sikap individu yang baik serta mendorong potensi sumber daya organisasi agar dapat bersaing dan berprestasi secara baik. 
Studi terdahulu dilakukan terhadap 319 guru tetap dari 27 SMA dan SMK swasta di Kota Madiun dan Kabupaten Madiun menunjukkan bahwa servant leadership yang merupakan pendekatan integrative leadership dapat mendorong keterikatan guru pada pekerjaan dan organisasi (employee engagement), perilaku ekstra-peran (OCB), dan kinerja guru (Srimulyani dkk. 2015). Studi lain terhadap 42 kepala sekolah di Inggris menunjukkan bahwa gaya kepemimpinan dapat mendorong para pelajar mencapai secara langsung prestasi akademik melalui iklim sekolah (Hay McBer 2000), artinya ketika kepala sekolah fleksibel dalam mendemonstrasikan gaya kepemimpinan dan berbagai macam kemampuan emotional intelligent yang dimilikinya, sikap guru lebih positif dan pelajar lebih tinggi nilainya.

Organizational justice dan employee engagement oleh banyak pengelola organisasi dianggap penting dan merupakan topik yang sedang hangat dibahas dalam wawasan manajemen sumber daya manusia saat ini. Robbin \& Judge (2008) menyatakan bahwa organizational justice adalah persepsi keseluruhan dari apa yang adil di tempat kerja. Hasil penelitian Imran (2007) menunjukkan bahwa perilaku kepemimpinan transaksional berpengaruh terhadap keadilan distributif dan perilaku kepemimpinan transformasional berpengaruh terhadap keadilan prosedural. Rahayu dan Surahman (2012) menemukan bahwa kepemimpinan berpengaruh positif signifikan terhadap employee engagement. Employee engagement yang tinggi ditunjukkan dalam tingkat keterlibatan, komitmen, keinginan para pegawai untuk berkontribusi dan tingginya rasa memiliki (ownership) terhadap pekerjaan dan organisasi, timbulnya rasa saling percaya (trust), tingginya loyalitas terhadap pekerjaan dan organisasi, serta kebanggaan terhadap organisasi dan tingginya semangat bekerjasama para pegawai.

Vondey (2010); Mira dan Margaretha (2012); Srimulyani dkk (2015) menemukan bahwa servant leadership berpengaruh signifikan terhadap OCB. OCB adalah sifat alami yang dimiliki pegawai yang merupakan peran ekstra sebagai pelengkap sistem organisasi yang dapat berkontribusi pada efektivitas organisasi (Choi et al. 2014; Elamin dan Tlaiss, 2015). Artinya dengan mengembangkan praktek servant leadership di organisasi diharapkan para pimpinan organisasi dapat menumbuhkan OCB dalam diri pegawai, yang dapat berdampak pada kelancaran operasional instansi dan keberhasilan instansi dalam mencapai tujuan yang telah ditetapkan, terlebih di era yang kompetitif saat ini. Dalam konteks manajemen pendidikan, guru merupakan bagian dari sumber daya manusia yang memiliki peran sentral dalam menentukan output pendidikan, karena guru merupakan pihak yang memiliki interaksi paling intensif dengan peserta didik, sehingga perannya banyak memberikan pengaruh terhadap cara berpikir, bersikap dan berperilaku peserta didik. Kontribusi guru dalam mewujudkan tujuan sekolah ditentukan oleh banyak faktor, salah satunya adalah seberapa besar kecenderungan guru dalam menunjukkan OCB.

Penelitian ini merupakan penelitian lanjutan dari penelitian sebelumnya (Srimulyani dkk. 2015) yang menemukan praktek integrative leadership dengan menggunakan kerangka konseptual servant leadership, yang terdiri dari empat kategori yaitu:1)character-orientation; 2)people-orientation;3)task-orientation;4)process-orientation. Sebagaimana yang telah dijelaskan sebelumnya bahwa praktek kepemimpinan dapat mempengaruhi keadilan organisasional, keterikatan pegawai, dan OCB, maka tujuan penelitian yang ditetapkan adalah untuk menguji dan menganalisis pengaruh integrative leadership terhadap organizational justice secara dimensional, employee engagement, dan OCB secara dimensional dengan responden guru-guru SMA/SMK/MAN/MAS di Kota Madiun. 


\section{KERANGKA TEORITIS DAN PENGEMBANGAN HIPOTESIS}

\section{Integrative Leadership}

Integrative leadership menurut Huxman \& Vangen (2000) didefinisikan sebagai kolaborasi antar individu, proses dan stuktur. Yulk (2002) menyatakan bahwa kerangka integrative leadership yaitu kepemimpinan yang mengintegrasikan variabel kemampuan, perilaku, fitur, sikap, gaya dan situasional dalam sebuah model teoritis tunggal untuk menjelaskan efektivitas organisasi. Integrative leadership juga didefinisikan sebagai integrasi dari perilaku kepemimpinan terhadap tugas, hubungan dan perubahan (Yulk et al. 2002). Integrative leadership menurut Fernadez et al. (2010) adalah perpaduan antara peran kepemimpinan yang berorientasi pada tugas, hubungan, perubahan, keragaman dan integrity. Fernandez et al. (2010) menyatakan bahwa integrative leadership adalah pendekatan kepemimpinan yang mengembangkan konsep kepemimpinan terpadu dengan mengintegrasikan lima peran kepemimpinan yang penting untuk kesuksesan pemimpin di sektor publik yaitu: kepemimpinann berorientasi pada tugas; kepemimpinan berorientasi pada hubungan; kepemimpinan berorientasi pada perubahan; kepemimpinan berorientasi pada keragaman, dan kepemimpinan berorientasi pada integritas.

Integrative leadership dengan kerangka konseptual servant leadership, hampir mirip dengan konsep integrative leadership dari Yulk et. al. (2002) memadukan empat kategori (Page dan Wong, 2003; Barbuto dan Wheeler, 2006; Liden et al. 2008) yaitu:

a. Character-orientation, berkenaan dengan sikap pemimpin; fokus pada nilai, kredibilitas dan motif pemimpin. Dimensi yang digunakan dalah wisdom dan humility.

b. People-orientation, berkenaan dengan mengembangkan sumber daya manusia; fokus pada hubungan pemimpin dengan bawahan dan komitmen pemimpin untuk mengembangkan bawahan. Dimensi yang digunakan adalah altruistic calling, dan emotional healing.

c. Task-orientation, berkenaan dengan pencapaian produktivitas dan keberhasilan; fokus pada tugas pemimpin dan keterampilan yang diperlukan untuk berhasil. Dimensi yang digunakan adalah organizational stewardship, persuasive mapping, dan vision.

d. Process-orientation, berkenaan dengan peningkatan efisiensi organisasi; fokus pada kemampuan pemimpin untuk mengembangkan sistem terbuka, efisien dan fleksibel. Dimensi yang digunakan adalah service.

\section{Organizational Justice}

Organizational justice adalah persepsi individu terhadap keadilan dalam proses pembuatan keputusan dan distribusi hasil yang telah diterima oleh individu (Greenberg \& Baron, 2003). Dimensi organizational justice meliputi distributive justice, procedural justice, dan interactional justice (Aamodt, 2007). Cropanzano et al. (2007) menjelaskan bahwa organizational justice merupakan motivator penting dalam suatu lingkungan pekerjaan, ketika individu merasakan suatu ketidakadilan, moral pegawai akan turun, dan kemungkinan besar pegawai akan meninggalkan pekerjaannya. Rasa keadilan akan muncul ketika otoritas organisasi konsisten dan tidak bias dalam pengambilan keputusan organisasi, terutama terkait dengan alokasi gaji dan promosi. 
Distributive justice merupakan evaluasi kognitif individu berkaitan dengan apakah jumlah dan alokasi penghargaan dalam penetapan secara adil atau tidak (Luthans, 2006: 293). Menurut Simpson \& Kaminski (2007) distributive justice menunjuk pada keadilan yang diterima dalam pemberian penghargaan di dalam suatu organisasi seperti pembayaran yang tepat dalam waktu dan jumlah yang diterima serta tingkat manfaatnya. Para pegawai mempertimbangkan keadilan dalam distribusi antara penghargaan finansial (misalnya gaji atau bonus yang diterima dari rencana pembagian keuntungan) dengan kontribusi para pegawai dalam pekerjaan, yang pada gilirannya mempengaruhi sikap para pegawai terhadap organisasi.

Procedural justice berhubungan dengan keadilan prosedur yang dipakai untuk membuat keputusan seperti kenaikan gaji, promosi, perubahan pekerjaan, dan umpan balik (Luthans 2006: 293), sedangkan menurut Coetzee (2005) procedural justice adalah kewajaran atas metode dan prosedur yang digunakan untuk menentukan keputusan atau outcomes. Keadilan prosedural mengacu kepada perasaan adil dari suatu proses pengambilan keputusan yang dibuat. Para pegawai menerima berbagai aspek yang berkaitan dengan keadilan prosedural ketika pegawai diberi kesempatan untuk mempengaruhi keputusan, untuk mengungkapkan ide atau suara, atau untuk memiliki informasi yang akurat yang digunakan untuk pengambilan keputusan.

Interactional justice adalah persepsi keadilan atas perlakuan interpersonal yang diterima pegawai ketika prosedur formal diterapkan baik yang dilakukan organisasi maupun atasan (Byrne, 2002). Menurut Bies (2005) interactional justice dihubungkan dengan penilaian keadilan berdasarkan kualitas perlakuan interpersonal yang diterima seorang pegawai dengan penuh martabat, perhatian, dan rasa hormat. Interactional justice terkait dengan kombinasi antara kepercayaan seorang bawahan terhadap atasannya dengan keadilan yang nampak dalam lingkungan kerja sehari-hari. Interactional justice biasanya mengacu kepada tingkat kejujuran, sensitivitas, dan penghormatan yang ditunjukkan selama interaksi (DeConnick, 2010).

Employee Engagement. Pengelolaan sumber daya manusia bukanlah suatu hal yang mudah karena berkaitan dengan bagaimana organisasi membuat pegawai menjadi nyaman sehingga memunculkan ikatan emosi (engage) dengan organisasi. Employee engagement didefinisikan sebagai keadaan motivasional positif yang mengandung karakteristik vigor, dedication, dan absorption (Schaufeli 2002). Vigor diartikan sebagai level energi yang tinggi, dan terdapat kemauan untuk menginvestasikan tenaga, presistensi dan tidak mudah lelah; dedication diartikan sebagai keterlibatan yang kuat yang ditandai oleh antusiasme dan rasa bangga dan inspirasi; absorption diartikan sebagai keadaan keterlibatan tinggi (terjun total) pada karyawan atas pekerjaannya (sulitnya memisahkan karyawan dari pekerjaannya) (Saks 2006). Pegawai yang masuk dalam kategori engaged melakukan pekerjaan dengan semangat, penuh dedikasi, dan menikmati proses pemenuhan tanggung jawabnya. Rasa engagement terhadap organisasi dipengaruhi oleh beberapa faktor seperti faktor emosional dan rasional yang berkaitan dengan pekerjaan dan pengalaman kerja secara keseluruhan. Menurut Baumruk dan Gorman (2006), jika pegawai memiliki rasa keterikatan yang tinggi dengan organisasi, hal tersebut akan meningkatkan tiga perilaku umum yang dapat meningkatkan kinerja organisasi: 
1) Say (mengatakan)-pegawai akan memberikan masukan untuk organisasi dan rekan kerjanya, dan akan memberikan masukan mengenai pegawai dan konsumen yang berpotensi;

2) Stay (tetap tinggal)-pegawai tetap akan bekerja di organisasi tersebut walaupun ada peluang untuk bekerja di tempat lain;

3) Strive (upaya)-pegawai akan memberikan lebih banyak waktu, usaha dan inisiatif untuk dapat berkontribusi demi kesuksesan organisasi

\section{Organizational Citizenship Behavior (OCB)}

Dalam dinamika kehidupan organisasi, khususnya organisasi nirlaba seperti organisasi kependidikan, diperlukan perilaku ekstra peran yang lazim disebut organizational citizenship behavior (OCB) atau extra-role behavior. Schnake dalam Alotaibi (2001: 4) mengartikan OCB sebagai "functional, extra-role, prosocial behavior, directed at individuals, group, and/or an organization." Hal ini menunjukkan bahwa OCB sebagai fungsional, ekstra peran, perilaku prososial, mengarahkan individu, kelompok atau organisasi. OCB mencerminkan tindakan-tindakan yang dilakukan oleh karyawan yang melampaui ketentuan minimum yang diharapkan oleh peran organisasi dan mempromosikan kesejahteraan rekan kerja, kelompok kerja, dan perusahaan (Lovell et al. dalam Mohammad \& Alias 2011). Jadi OCB merupakan perilaku pegawai yang melampui tugas atau peran formalnya yang telah ditetapkan tanpa adanya permintaan dan reward secara formal dari organisasi dan memberikan kontribusi terhadap keefektifan organisasi.

Dimensi pengukuran OCB menurut Organ et al.(2006) adalah sebagai berikut:

a. Helping Behavior/Altruism; perilaku anggota organisasi dalam menolong rekan kerja dengan sukarela yang mengalami kesulitan dalam situasi yang sedang dihadapi baik mengenai tugas dalam organisasi maupun masalah pribadi orang lain. Dimensi ini disebut juga altruism, peacemaking atau cheerleading.

b. Courtesy; perilaku yang menjaga hubungan baik dengan rekan kerjanya agar terhindar dari masalah-masalah interpersonal dengan menunjukkan perilaku yang menghargai dan memperhatikan orang lain.

c. Individual Initiative/Conscientiousness; suatu perilaku yang menunjukkan upaya sukarela dalam meningkatkan kreatifitas dalam menjalankan tugasnya agar kinerja organisasi meningkat, perilaku yang ditunjukkan dengan berusaha melebihi yang diharapkan organisasi, misalnya inisiatif meningkatkan kompetensinya, secara sukarela mengambil tanggungjawab di luar wewenangnya atau panggilan tugasnya.

d. Sportsmanship; perilaku yang menunjukkan suatu kerelaan atau toleransi terhadap keadaan yang kurang ideal dalam organisasi tanpa mengajukan keberatan-keberatan atau keluhan-keluhan sehingga meningkatkan iklim yang positif diantara anggota organisasi, lebih sopan, dan mau bekerja sama dengan yang lain sehingga akan menciptakan lingkungan kerja yang lebih menyenangkan.

e. Civic Virtue/Organizational Participation; perilaku yang mengindikasikan tanggung jawab pada kehidupan organisasi, terlibat dalam aktivitas organisasi dan peduli terhadap kelangsungan hidup organisasi (mengikuti perubahan dalam organisasi, mengambil inisiatif untuk merekomendasikan bagaimana operasi atau prosedur-prosedur organisasi dapat diperbaiki, dan melindungi sumber-sumber yang dimiliki oleh organisasi). 
Sebuah pandangan yang berbeda pada dimensi dari $O C B$ datang dari Williams dan Anderson dalam Mohammad dan Alias (2011), dimana OCB dibagi menjadi dua jenis:

a. Citizenship behaviors directed toward individuals (OCB-I) meliputi perilaku diarahkan pada hubungan antara individu dalam organisasi, seperti courtesy dan altruism. OCB-I adalah perilaku yang menguntungkan individu-individu tertentu dalam suatu organisasi dan dengan demikian secara tidak langsung berkontribusi terhadap efektivitas organisasi (Lee \& Allen 2002). Podsakoff et al. dalam Mohammad \& Alias (2011) menyatakan bahwa individu sukarela membantu orang lain yang berhubungan dengan pekerjaannya.

b.Citizenship behaviors directed towards the organisation (OCB-O) berkaitan dengan perilaku menguntungkan organisasi secara keseluruhan atau hubungan individu dengan organisasi, seperti conscientiousness, sportsmanship, dan civic virtue. OCB-O merupakan perilaku menguntungkan perusahaan tanpa tindakan yang ditujukan secara spesifik untuk setiap anggota lain dalam perusahaan (misalnya mengikuti aturan informal, sukarelawan untuk komite). Williams dan Anderson dalam Mohammad \& Alias (2011) mendefinisikan OCB-O sebagai perilaku yang menguntungkan perusahaan pada umumnya, termasuk perilaku mengikuti aturan yang dirancang untuk menjaga ketertiban di dalam perusahaan.

Hasil penelitian Srimulyani dkk. (2015) menunjukkan integrative leadership yang diukur dengan kerangka konsep servant leadership berpengaruh positif signifikan terhadap employee engagement, perilaku ekstra-peran, dan kinerja guru. Hasil penelitian tersebut sejalan Rahayu dan Surahman (2012) yang menemukan bahwa kepemimpinan berpengaruh positif signifikan terhadap employee engagement. Engagement merupakan variabel yang berpengaruh terhadap produktivitas (kinerja), sehingga sangat penting bagi pengelola organisasi untuk berfokus meningkatkan engagement pegawai dalam bekerja. Peningkatan employee engagement dapat dilakukan melalui praktek integrative leadership, semakin tinggi praktek integrative leadership semakin tinggi pula tingkat employee engagement dan perilaku ekstra-peran pegawai, demikian sebaliknya. Berdasarkan hasil penelitian sebelumnya, dirumuskan hipotesis penelitian sebagai berikut:

Hla:Integrative leadership berpengaruh positif signifikan terhadap distributive justice.

Hlb:Integrative leadership berpengaruh positif signifikan terhadap procedural justice.

$\mathrm{H} 1 \mathrm{c}$ :Integrative leadership berpengaruh positif signifikan terhadap interactional justice.

$\mathrm{H} 2$ :Integrative leadership berpengaruh positif signifikan terhadap employee engagement.

H3a:Integrative leadership berpengaruh positif signifikan terhadap organizational citizenship behavior organization (OCB-O).

H3b:Integrative leadership berpengaruh positif signifikan terhadap organizational citizenship behavior individual (OCB-I). 


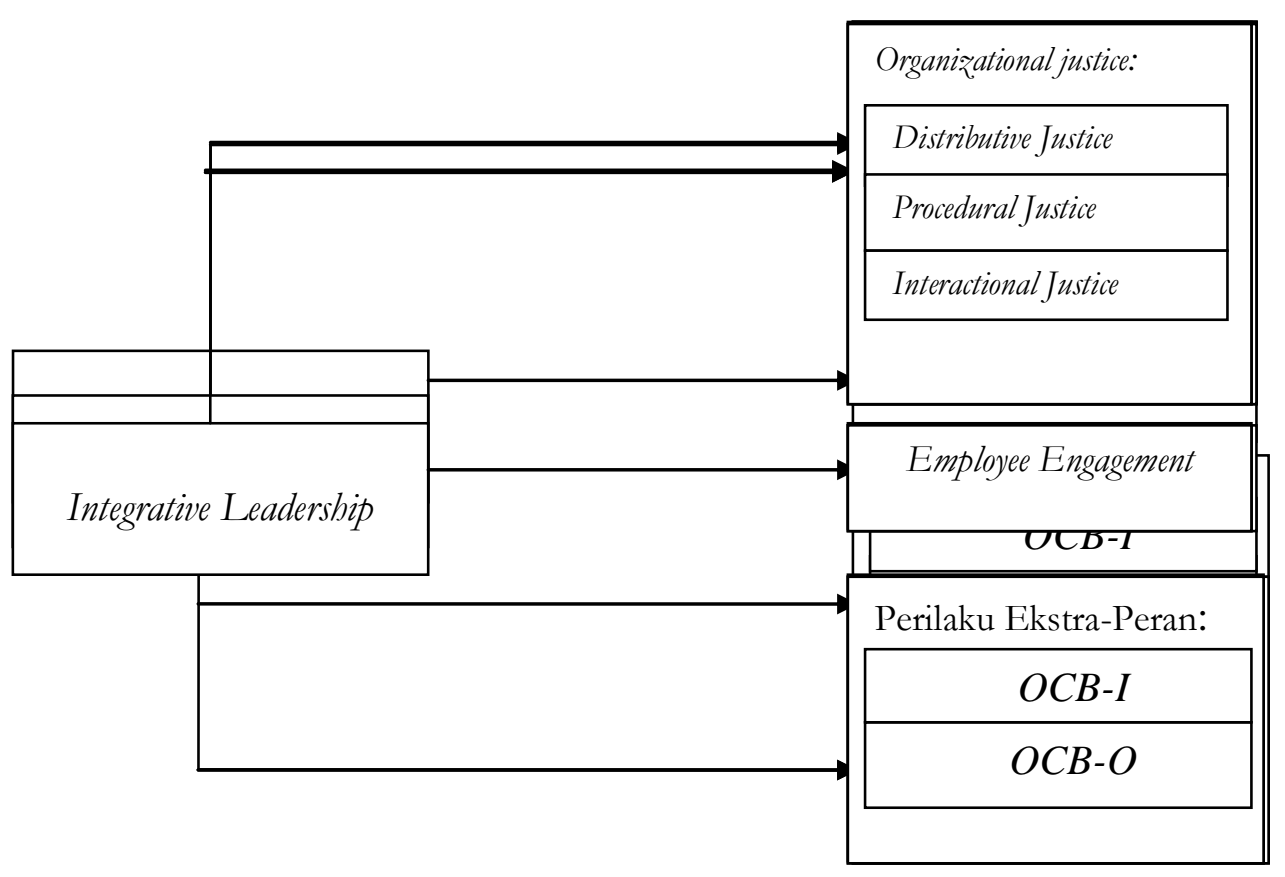

\section{METODE PENELITIAN}

Gambar 1. Model Penelitian

Berdasarkan variabel yang diteliti, jenis penelitian ini merupakan penelitian deskriptif verifikatif dan metode penelitian yang digunakan adalah metode explanatory survey. Metode penelitian dengan mengambil sampel dari suatu populasi dengan menggunakan kuesioner sebagai alat pengumpul data yang utama. Pengambilan data primer dilakukan dengan menggunakan kuesioner. Penelitian dilakukan di wilayah Kota Madiun dengan obyek penelitian guru tetap dari SMA/SMK/MAN/MAS di kota Madiun. Penentuan sampel menggunakan metode nonprobability sampling yaitu convenience sampling. Convenience sampling merupakan metode yang unrestricted yang memungkinkan peneliti mengambil elemen populasi dengan mudah. Survei dilakukan dengan menyebarkan kuesioner pada guru-guru SMA/SMK/MAN/MAS di Kota Madiun. Analisis pendahuluan yang dilakukan adalah pengujian kualitas data penelitian (Uji validitas dan uji reliabilitas) dan pengujian asumsi klasik. Hipotesis diuji dengan analisis regresi linier berganda, dengan menggunakan uji t. Analisis data dilakukan dengan software SPSS. 
Tabel 1. Pengukuran dan definisi operasional variabel penelitian

\begin{tabular}{|c|c|c|c|c|}
\hline Variabel & Definisi Operasional & Dimensi & $\begin{array}{l}\text { Jumlah } \\
\text { Indikator }\end{array}$ & Literatur \\
\hline $\begin{array}{l}\text { Integrative } \\
\text { Leadership }\end{array}$ & $\begin{array}{l}\text { Praktek kepemimpinan } \\
\text { yang berorientasi } \\
\text { pada:1)character- } \\
\text { orientation, berkenaan } \\
\text { dengan sikap pemimpin; } \\
\text { 2)people-orientation, } \\
\text { berkenaan dengan } \\
\text { pengembangan sumber } \\
\text { daya manusia;3)task- } \\
\text { orientation, berkenaan } \\
\text { dengan pencapaian } \\
\text { produktivitas dan } \\
\text { keberhasilan; 4)Process- } \\
\text { orientation, berkenaan } \\
\text { dengan peningkatan } \\
\text { efisiensi organisasi; }\end{array}$ & $\begin{array}{l}\text { Wisdom } \\
\text { Humality } \\
\text { Altruistic calling } \\
\text { Emotional } \\
\text { healing } \\
\text { Persuasive } \\
\text { mapping } \\
\text { Organizational } \\
\text { stewardship } \\
\text { Vision } \\
\text { Service }\end{array}$ & $\begin{array}{l}4 \text { indikator } \\
6 \text { indikator } \\
5 \text { indikator } \\
4 \text { indikator } \\
5 \text { indikator } \\
5 \text { indikator } \\
5 \text { indikator } \\
5 \text { indikator } \\
\text { Skala: } \\
\text { skala Likert } \\
\text { dari } 1 \text { sd. } \\
5 \text { poin. }\end{array}$ & $\begin{array}{l}\text { Barbuto \& } \\
\text { Wheeler } \\
\text { (2006) Page } \\
\text { \&Wong } \\
\text { (2003) }\end{array}$ \\
\hline $\begin{array}{l}\text { Organizatio- } \\
\text { nal Justice }\end{array}$ & $\begin{array}{l}\text { Persepsi keseluruhan dari } \\
\text { apa yang adil di tempat } \\
\text { kerja, yang meliputi } \\
\text { distributive justice adalah } \\
\text { keadilan jumlah imbalan } \\
\text { yang dirasakan diantara } \\
\text { individu; } \\
\text { procedural justice } \\
\text { adalah keadilan yang } \\
\text { dirasakan dari proses } \\
\text { yang } \\
\text { digunakan untuk } \\
\text { menentukan distribusi } \\
\text { imbalan; } \\
\text { interactional justice } \\
\text { adalah persepsi individu } \\
\text { tentang tingkat sampai } \\
\text { dimana seorang } \\
\text { pegawai diperlakukan } \\
\text { dengan penuh } \\
\text { martabat, perhatian, } \\
\text { rasa hormat. }\end{array}$ & $\begin{array}{l}\text { Distributive } \\
\text { Justice } \\
\text { Procedural } \\
\text { Justice } \\
\text { Interactional } \\
\text { Justice }\end{array}$ & $\begin{array}{l}4 \text { indikator } \\
7 \text { indikator } \\
8 \text { indikator } \\
\text { Skala: } \\
\text { skala Likert } \\
\text { dari } 1 \text { sd. } 5 \\
\text { poin. }\end{array}$ & $\begin{array}{l}\text { Robbins } \\
\text { dan Judge } \\
\text { (2008); } \\
\text { Cohen- } \\
\text { Carash \& } \\
\text { Spector, } \\
\text { (2001); } \\
\text { Colquitt } \\
\text { (2001) }\end{array}$ \\
\hline $\begin{array}{l}\text { Employee } \\
\text { Engagement }\end{array}$ & $\begin{array}{l}\text { Menggambarkan } \\
\text { sebagai sikap positif } \\
\text { seseorang (pegawai) } \\
\text { yang meliputi komitmen, } \\
\text { keterlibatan dan } \\
\text { keterikatan terhadap } \\
\text { nilai-nilai budaya dan }\end{array}$ & $\begin{array}{l}\text { Vigor } \\
\text { Dedication } \\
\text { Absorption }\end{array}$ & $\begin{array}{l}6 \text { indikator } \\
5 \text { indikator } \\
6 \text { indikator } \\
\text { Skala: } \\
\text { skala Likert } \\
\text { dari } 1 \text { sd. } 5 \\
\text { poin. }\end{array}$ & $\begin{array}{l}\text { Schaufeli et } \\
\text { al. (2002) }\end{array}$ \\
\hline
\end{tabular}




\begin{tabular}{|c|c|c|c|c|}
\hline & $\begin{array}{l}\text { pencapaian } \\
\text { keberhasilan organisasi }\end{array}$ & & & \\
\hline $\begin{array}{l}\text { Organizatio- } \\
\text { nal Citizenship } \\
\text { Behavior } \\
\text { (OCB) }\end{array}$ & $\begin{array}{l}\text { Merupakan perilaku } \\
\text { yang melekat pada } \\
\text { individu dalam } \\
\text { organisasi, bersifat bebas } \\
\text { dan sukarela melebihi } \\
\text { ketentuan peran yang } \\
\text { dipersyaratkan oleh } \\
\text { organisasi dan } \\
\text { munculnya perilaku } \\
\text { tersebut memberikan } \\
\text { manfaat bagi organisasi } \\
\text { dimana perilaku tersebut } \\
\text { tidak berkaitan langsung } \\
\text { dengan sistem } \\
\text { penghargaan organisasi }\end{array}$ & $\begin{array}{l}\text { OCB-I: } \\
\text { Altruism } \\
\text { Courtesy } \\
\text { OCB-O: } \\
\text { Conscientiousness } \\
\text { Sportsmanship } \\
\text { Civic Virtue }\end{array}$ & $\begin{array}{l}3 \text { indikator } \\
3 \text { indikator } \\
3 \text { indikator } \\
3 \text { indikator } \\
3 \text { indikator } \\
\text { Skala: } \\
\text { skala Likert } \\
\text { dari } 1 \text { sd. } 5 \\
\text { poin. }\end{array}$ & $\begin{array}{l}\text { Organ et. } \\
\text { al. (2006) }\end{array}$ \\
\hline
\end{tabular}

\section{ANALISIS DATA DAN PEMBAHASAN}

Jumlah sekolah swasta di Kota Madiun yang menjadi obyek penelitian berjumlah 40 (empat puluh) SMA/SMK/MAN/MAS, dan yang bersedia disurvei sebanyak 30 sekolah yang terdiri dari 9 sekolah negeri dan 21 sekolah swasta. Kuesioner yang disebarkan sebanyak 423 kuesioner bagi guru di 30 SMA/SMK/MAN/MAS, dengan respon rate 96,70\% (sejumlah 409 kuesioner yang kembali). Profil responden penelitian yang meliputi jenis kelamin, tingkat pendidikan, dan masa kerja disajikan pada tabel 2.

Tabel 2. Profil Responden

\begin{tabular}{|l|c|c|}
\hline \multicolumn{1}{|c|}{ Keterangan } & $\begin{array}{c}\text { Jumlah } \\
\text { (Orang) }\end{array}$ & $\begin{array}{c}\text { Presentase } \\
\text { (\%) }\end{array}$ \\
\hline Jenis Kelamin & & \\
\hline Laki-laki & 184 & 44,98 \\
\hline Perempuan & 225 & 55,02 \\
\hline Jumlah & 409 & 100 \\
\hline Tingkat Pendidikan & & \\
\hline Strata 1 (S1) & 365 & 89,92 \\
\hline Strata 2 (S2) & 44 & 10,08 \\
\hline Jumlah & 409 & 100 \\
\hline Masa Kerja & & \\
\hline$\leq 5$ tahun & 76 & 18,58 \\
\hline$>5$ tahun s.d. $\leq 10$ tahun & 71 & 17,36 \\
\hline$>10$ tahun s.d. $\leq 20$ tahun & 156 & 38,14 \\
\hline$>20$ tahun s.d. $\leq 30$ tahun & 89 & 21,76 \\
\hline$>30$ tahun & 17 & 4,16 \\
\hline Jumlah & 409 & 100 \\
\hline Sumbr: Data pimer, 2016 &
\end{tabular}

Sumber: Data primer, 2016 
Jika dilihat dari jenis kelamin sebanyak $44,98 \%$ responden berjenis kelamin laki-laki dan $55,02 \%$ berjenis kelamin perempuan. Jika dilihat dari tingkat pendidikan sebagian besar responden $(89,92 \%)$ memiliki tingkat pendidikan strata 1 (S1) dan sebagian kecil $(10,08 \%)$ memiliki tingkat pendidikan strata 2 (S2). Jika dilihat dari masa kerja, sebanyak 18,58\% memiliki masa kerja $\leq 5$ tahun; sebanyak $17,36 \%$ memiliki masa kerja $>5$ tahun s.d. $\leq 10$ tahun; sebanyak $38,14 \%$ memiliki masa kerja $>10$ tahun s.d. $\leq 20$ tahun; sebanyak $21,76 \%$ memiliki masa kerja $>20$ tahun s.d. $\leq 30$ tahun; dan 4,16\% memiliki masa kerja>30 tahun.

Tabel 3.Rata-rata Variabel Penelitian antara SMA/SMK/MAN/MAS Kota Madiun

\begin{tabular}{|l|c|c|c|c|}
\hline \multicolumn{1}{|c|}{ Variabel } & Kepemilikan & N & Mean & Keterangan \\
\hline \multirow{2}{*}{ Integrative Leadership } & 1 & 262 & 4.0 & Tinggi \\
\cline { 2 - 5 } & 2 & 147 & 4.0 & Tinggi \\
\hline Distributive Justice & 1 & 262 & 3.5 & Tinggi \\
\hline Procedural Justice & 1 & 147 & 3.6 & Tinggi \\
\cline { 2 - 5 } & 2 & 147 & 3.6 & Tinggi \\
\hline Interactional Justice & 1 & 262 & 3.8 & Tinggi \\
\cline { 2 - 5 } & 2 & 147 & 3.6 & Tinggi \\
\hline \multirow{2}{*}{\begin{tabular}{l} 
Employee Engagement \\
\cline { 2 - 5 }
\end{tabular}} & 1 & 262 & 3.7 & Tinggi \\
\hline Organizational Citizenship & 1 & 262 & 3.9 & Tinggi \\
\hline Behaviors-Organization & 2 & 147 & 3.9 & Tinggi \\
\hline $\begin{array}{l}\text { Organizational Citizenship } \\
\text { Behaviors-Individual }\end{array}$ & 1 & 262 & 3.9 & Tinggi \\
\hline $\begin{array}{l}\text { Organizational Citizenship } \\
\text { Behaviors }\end{array}$ & 2 & 147 & 3.8 & Tinggi \\
\cline { 2 - 5 } & 1 & 262 & 4.0 & Tinggi \\
\hline
\end{tabular}

Keterangan: 1=Swasta; $2=$ Negeri

Dari tabel 3 dapat dilihat bahwa mean atau rerata kelompok 1 (sekolah negeri) dan kelompok 2 (sekolah swasta) ada beberapa variabel yang rerata jawaban responden sama dan ada beberapa variabel yang rerata jawaban responden berbeda. Penafsiran tinggirendahnya rata-rata jawaban responden atas variabel yang diteliti, berdasarkan rentang skala yang digunakan dalam instrumen penelitian yaitu skala 5 point $(5-1=4 / 5=0,8)$, sehingga rentang skala untuk penafsiran peringkat sebesar 0.8. Pengujian kualitas data dilakukan pada 100 jawaban dari 409 jawaban dan hasilnya memenuhi kriteria validitas dan reliabilitas. Demikian juga untuk pengujan asumsi klasik yang meliputi: uji normalitas data, uji multikolinieritas, uji heteroskedastidas, dan uji autokorelasi dilakukan atas persamaan regresi yang dikembangkan dan hasilnya memenuhi kriteria asumsi klasik. Analisis berikutnya adalah uji hipotesis dengan uji † yaitu alat uji untuk mengetahui dan mengukur variabel-variabel yang mempunyai keeratan pengaruh terhadap variabel terikat ( $Y$ ) secara parsial yaitu dengan membandingkan antara thitung dan t tabel pada tingkat keyakinan $5 \%(a=0,05)$ dengan pengujian satu arah. Untuk $t$ tabel dicari dengan tabel $\dagger$ dengan $d f=n-k$, dimana $k$ 
merupakan jumlah variabel independen (Nugroho, 2005: 54). Nilai-nilai koefisien regresi dan t-hitungnya (CR) diestimasi dari hasil analisis regresi, yang diolah dengan SPSS versi 18 dapat dilihat pada tabel 4.

Tabel 4. Ringkasan Hasil Analisis Regresi

\begin{tabular}{|c|c|c|c|c|c|c|c|c|}
\hline & & Estimate & S.E. & $\begin{array}{c}\text { Standardized } \\
\text { Coefficients } \\
\text { Beta }\end{array}$ & $\begin{array}{l}\text { C.R. } \\
\text { (t-hit) }\end{array}$ & T tabel & $P$ & Keterangan \\
\hline \multicolumn{9}{|c|}{ 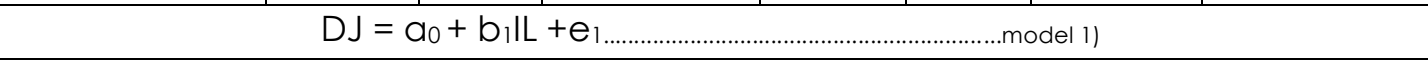 } \\
\hline $\mathrm{IL}$ & $\rightarrow$ DJ & 0,689 & 0,074 & 0,420 & 9,329 & 1,966 & 0,000 & Signifikan \\
\hline \multicolumn{9}{|c|}{$\mathrm{PJ}=\mathrm{a}_{0}+\mathrm{b}_{1} \mathrm{~L}+\mathrm{e}_{1} \ldots \ldots \ldots \ldots \ldots \ldots \ldots$ model 2$)$} \\
\hline & $\rightarrow \mathrm{PJ}$ & 0,788 & 0,043 & 0,676 & 18,487 & 1,966 & 0,000 & Signifikan \\
\hline \multicolumn{9}{|c|}{ 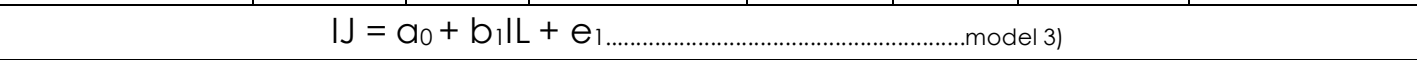 } \\
\hline IL & $\rightarrow \quad \mathrm{IJ}$ & 0,972 & 0,073 & 0,548 & 13,232 & 1,966 & 0,000 & Signifikan \\
\hline \multicolumn{9}{|c|}{ 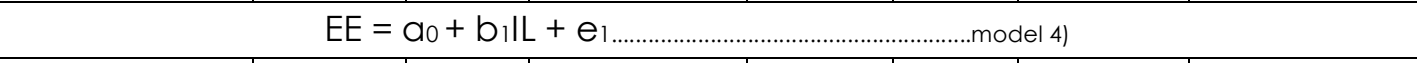 } \\
\hline IL & $\mathrm{EE}$ & 0,432 & 0,067 & 0,305 & 6,470 & 1,966 & 0,000 & Signifikan \\
\hline \multicolumn{9}{|c|}{$\mathrm{OCBO}=\mathrm{a}_{0}+\mathrm{b}_{1} \mathrm{lL}+\mathrm{b}_{2} \mathrm{EE}+\mathrm{e}_{1} \ldots \ldots \ldots \ldots \ldots \ldots \ldots \ldots \ldots \ldots \ldots \ldots \ldots \ldots \ldots$ model 5$)$} \\
\hline & $\rightarrow \mathrm{OCBO}$ & 0,184 & 0,039 & 0,208 & 4,730 & 1,966 & 0,000 & Signifikan \\
\hline & $\rightarrow \mathrm{OCBO}$ & 0,275 & 0,027 & 0,439 & 9,995 & 1,966 & 0,000 & Signifikan \\
\hline \multicolumn{9}{|c|}{ 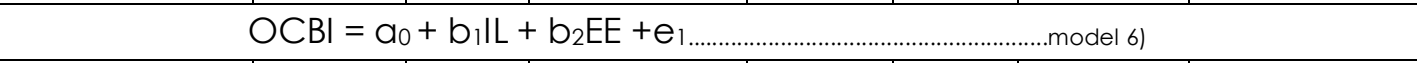 } \\
\hline & $\rightarrow \mathrm{OCBI}$ & 0,198 & 0,047 & 0,195 & 4,228 & 1,966 & 0,000 & Signifikan \\
\hline & $\rightarrow \mathrm{OCBI}$ & 0,261 & 0,033 & 0,364 & 7,866 & 1,966 & 0,000 & Signifikan \\
\hline
\end{tabular}

Sumber: Output SPSS.

Berdasarkan tabel 4 nilai koefisien regresi integrative leadership (IL) pada model 1 sebesar 0,689 dengan taraf signifikan $5 \%$, nilai $t$ hitung sebesar 9,329>1,966 dan nilai signifikansi sebesar $0,000<0,05$ maka dapat disimpulkan variabel integrative leadership berpengaruh secara positif signifikan terhadap distributive justice (DJ). Hal ini berarti hipotesis ( $\mathrm{Hl}$ a) yang menyatakan: integrative leadership berpengaruh positif signifikan terhadap distributive justice, diterima. Nilai koefisien regresi integrative leadership (IL) pada model 2 sebesar 0,788 dengan taraf signifikan $5 \%$, nilai t hitung sebesar 18,487>1,966 dan nilai signifikansi sebesar $0,000<0,05$ maka dapat disimpulkan variabel integrative leadership berpengaruh secara positif signifikan terhadap procedural justice (PJ). Hal ini berarti hipotesis ( $\mathrm{Hl}$ b) yang menyatakan: integrative leadership berpengaruh positif signifikan terhadap procedural justice, diterima. Nilai koefisien regresi integrative leadership (IL) pada model 3 sebesar 0,972 dengan taraf signifikan $5 \%$, nilai t hitung sebesar 13,232>1,966 dan nilai signifikansi sebesar $0,000<0,05$ maka dapat disimpulkan variabel integrative leadership berpengaruh secara positif signifikan terhadap interactional justice (IJ). Hal ini berarti hipotesis (HlC) yang menyatakan: integrative leadership berpengaruh positif signifikan terhadap interactional justice, diterima.

Berdasarkan tabel 4 nilai koefisien regresi integrative leadership (IL) pada model 4 sebesar 0,432 dengan taraf signifikan $5 \%$, nilai † hitung sebesar $6,470>1,966$ dan nilai signifikansi sebesar 0,000 yang lebih kecil dari taraf signifikansi 0,05 maka dapat disimpulkan variabel integrative leadership berpengaruh secara positif signifikan terhadap employee 
engagement (EE). Hal ini berarti hipotesis $(\mathrm{H} 2)$ yang menyatakan: integrative leadership berpengaruh positif signifikan terhadap employee engagement, diterima.

Berdasarkan tabel 4 nilai koefisien regresi integrative leadership (IL) pada model 5 sebesar 0,184 dengan taraf signifikan $5 \%$, nilai $\dagger$ hitung sebesar $7,866>1,966$ dan nilai signifikansi sebesar 0,000<0,05 maka dapat disimpulkan variabel integrative leadership berpengaruh secara positif signifikan terhadap employee engagement (EE). Hal ini berarti hipotesis $(\mathrm{H} 3 \mathrm{a})$ yang menyatakan: integrative leadership berpengaruh positif signifikan terhadap organizational citizenship behavior-organization (OCB-O), diterima. Nilai koefisien regresi integrative leadership (IL) pada model 6 sebesar 0,198 dengan taraf signifikan $5 \%$, nilai $\dagger$ hitung sebesar 4,228>1,966 nilai signifikansi sebesar 0,000<0,05 maka dapat disimpulkan variabel integrative leadership berpengaruh secara positif signifikan terhadap employee engagement (EE). Hal ini berarti hipotesis ( $\mathrm{H} 3 \mathrm{~b})$ yang menyatakan: integrative leadership berpengaruh positif signifikan terhadap organizational citizenship behavior-individual (OCBI), diterima.

\section{PEMBAHASAN DAN KESIMPULAN Pengaruh Integrative Leadership terhadap Organizational Justice}

Integrative leadership adalah perpaduan antara peran kepemimpinan yang berorientasi pada tugas, hubungan, perubahan, keragaman dan integrity, dimana integrative leadership merupakan konsep kepemimpinan terpadu dengan mengintegrasikan lima peran kepemimpinan yang penting untuk kesuksesan pemimpin di suatu organisasi yaitu: kepemimpinan berorientasi pada pengembangan karakter; kepemimpinan berorientasi pada manusia; kepemimpinan berorientasi pada tugas, dan kepemimpinan berorientasi pada proses. Hasil pengujian hipotesis menunjukkan bahwa praktek integrative leadership berdampak positif dan signifikan pada praktek keadilan organisasional, baik keadilan distributif, keadilan prosedural, dan keadilan organisasional. Hal ini mengindikasikan setiap organisasi sebaiknya mengevaluasi kepemimpinan yang dijalankan secara kontinue karena pada akhirnya, pertumbuhan persepsi positif tentang rasa keadilan akan membantu pertumbuhan organisasi. Pemimpin diharapkan untuk menerapkan keadilan dalam tempat kerja karena keadilan organisasional (organizational justice) dapat direfleksikan dalam perilaku pemimpin yang dianggap adil oleh pekerja. Karena setiap anggota organisasi memiliki kepekaan yang kuat (strong sense) terhadap keadilan, maka pemimpin perlu mempertimbangkan prinsip keadilan saat membuat keputusan. Setiap keputusan ini akan mempengaruhi keadilan yang dirasakan para pekerja.

Kepemimpinan integratif adalah praktek kepemimpinan yang fokus pada pengembangan sikap, nilai, kredibilitas dan motif; berorientasi pada pengembangan sumber daya manusia serta fokus pada hubungan pemimpin dengan bawahan dan komitmen pemimpin untuk mengembangkan bawahan; berorientasi pada tugas dengan menekankan pencapaian produktivitas dan keberhasilan; serta berorientasi pada peningkatan efisiensi organisasi melalui pengembangan sistem terbuka, efisien dan fleksibel. Praktek integrative leadership dapat berdampak pada semakin positif persepsi bawahan atas keadilan distributif. Misalnya, adilnya hasil keputusan manajerial sehingga dapat mempengaruhi kepuasan individu dengan berbagai pekerjaan yang berhubungan dengan hasil seperti gaji, tugas kerja, pengakuan, dan kesempatan untuk kemajuan. Praktek integrative leadership dapat berdampak juga pada persepsi anggota organisasi atas keadilan prosedural yaitu persepsi 
individu dari keadilan yang digunakan untuk menentukan berbagai hasil, misalnya dalam proses penilaian kinerja anggota organisasi yang adil, dapat membuat anggota organisasi lebih termotivasi untuk berpartisipasi dalam kegiatan, mengikuti aturan, dan menganggap hasil yang relevan adalah adil. Namun sebaliknya jika para anggota organisasi merasa adanya ketidakadilan dalam hal prosedural, maka anggota organisasi cenderung menarik diri dari kesempatan untuk berpartisipasi, kurang memperhatikan aturan dan kebijakan, dan menganggap hasil yang relevan adalah tidak adil. Praktek kepemimpinan integratif dapat berdampak juga pada persepsi anggota organisasi atas keadilan interpersonal terkait dengan tingkat keadilan anggota organisasi dalam melihat bagaimana seorang anggota organisasi diperlakukan oleh pihak lain dalam organisasi tempat kerja. Misalnya, seorang bawahan diperlakukan oleh pimpinan dengan bermartabat dan hormat, pimpinan juga menyediakan informasi secara tepat waktu, dan selalu terbuka dan jujur dalam hubungannya dengan bawahan, maka bawahan akan mengekspresikan keadilan interaksional yang tinggi dengan pimpinannya, sebaliknya jika pimpinan memperlakukan bawahannya dengan kurang hormat, dan menahan informasi penting, sering ambigu atau tidak jujur dalam hubungannya dengan bawahan, bawahan akan mengalami ketidakadilan interaksional.

\section{Pengaruh Integrative Leadership terhadap Employee Engagement}

Dari hasil uji hipotesis diperolah hasil variabel integrative leadership berpengaruh secara signifikan terhadap employee engagement, dengan arah positif. Hal ini dapat dilihat dari nilai signifikansinya sebesar 0,000 yang lebih kecil dari taraf signifikansi 0,05. Hasil penelitian ini sejalan Rahayu dan Surahman (2012) yang menemukan bahwa kepemimpinan berpengaruh signifikan terhadap employee engagement, dimana dalam penelitian ini praktek kepemimpinan ditinjau dari dimensi servant leadership. Engagement merupakan variabel yang berpengaruh terhadap produktivitas (kinerja) dan kepuasan pelanggan, dan juga mengurangi turnover, sehingga amat penting bagi sebuah organisasi untuk berfokus untuk meningkatkan engagement anggota organisasi dalam bekerja. Pencapaian employee engagement dapat diupayakan melalui gaya kepemimpinan, dan salah satu gaya atau pendekatan kepemimpinan yang dikaji adalah integrative leadership. Praktek kepemimpinan integratif ditinjau dari pendekatan servant leadership di organisasi pendidikan yang dilihat dari aspek: altruistic calling, emotional healing, wisdom, persuasive mapping, organizational stewardship, vision, dan service, dapat berdampak pada tingkat employee engagement para guru, sehingga para guru memiliki keterlibatan penuh dan memiliki semangat bekerja tinggi dalam pekerjaannya maupun dalam hal-hal yang berkaitan dengan kegiatan sekolah dalam jangka panjang, yang pada akhirnya dapat mempengaruhi kinerja guru dan kepuasan para peserta didik. Semakin tinggi praktek integrative leadership semakin tinggi pula tingkat employee engagement anggota organisasi, demikian sebaliknya. Employee engagement dilihat dari aspek: 1)vigor; merupakan curahan energi dan mental yang kuat seseorang selama bekerja, keberanian untuk berusaha sekuat tenaga dalam menyelesaikan suatu pekerjaan, dan tekun dalam menghadapi kesulitan kerja, kemauan untuk menginvestasikan segalaupaya dalam suatu pekerjaan, dan tetap bertahan meskipun menghadapi kesulitan; 2)dedication; perasaan terlibat sangat kuat dalam suatu pekerjaan dan mengalami rasa kebermaknaan, antusiasme, kebanggaan, inspirasi, dan tantangan; 3)absorption; merupakan konsentrasi penuh dan keseriusan seseorang dalam bekerja. 


\section{Pengaruh Integrative Leadership terhadap Organizational Citizenship Behavior}

Dimensi OCB dibagi ke dalam dua kategori:1)OCB-O, yaitu perilaku-perilaku yang memberikan manfaat bagi organisasi pada umumnya, meliputi dimensi: conscientiousness, civic virtue, dan sportsmanship; 2)OCB-I, yaitu perilaku-perilaku yang secara langsung memberikan manfaat bagi individu lain dan secara tidak langsung juga memberikan kontribusi pada organisasi, meliputi dimensi: courtessy dan altruism.

Dari hasil uji hipotesis diperolah hasil variabel integrative leadership berpengaruh secara positif signifikan terhadap organizational citizenship behavior (OCB) baik dimensi OCB-O, yaitu perilaku-perilaku yang memberikan manfaat bagi organisasi pada umumnya, meliputi dimensi: civic virtue, conscientiousness, dan sportsmanship serta dimensi OCB-I yang meliputi: courtessy dan altruism. Hasil penelitian ini sejalan Srimulyani (2010) ditemukan pengaruh signifikan kepemimpinan transformasional terhadap OCB dan Vondey (2010) membuktikan bahwa servant leadership berhubungan OCB, serta mendukung Mira dan Margaretha (2012) menemukan bahwa servant leadership berpengaruh signifikan terhadap OCB.

OCB dapat didefinisikan sebagai perilaku sukarela/exstra-role behavior yang tidak termasuk dalam uraian jabatan, perilaku spontan/tanpa saran atau perintah seseorang, perilaku yang bersifat yang bersifat menolong, contohnya seperti membantu rekan kerja untuk lebih cepat menyelesaikan tugas kerjanya dengan sukarela di saat pekerjaanya sudah selesai terlebih dulu. Dimensi OCB meliputi: helping/altruism, conscientiousness, sportsmanship, courtessy dan civic virtue. Integrative leadership yang dilihat dari pendekatan servant leadership merupakan perilaku dalam konteks pelayanan dalam suatu kegiatan dengan rekan kerja dan kebutuhan para pengikut (follower) dalam organisasi serta yang dapat memberikan manfaat bagi organisasi dan pengikutnya. Seorang servant leader melakukan tindakan yang melayani dengan sukarela, seperti menolong dan memberikan konstribusi pada bawahannya berupa pengajaran, kasih, pengalaman, atau nasehat. Perilaku pemimpin yang mencerminkan servant leader di organisasi pendidikan sangat mempengaruhi OCB pada para guru, karena para guru cenderung meniru apa yang dilakukan oleh pemimpinnya. Dengan demikian, dapat disimpulkan bahwa apabila pemimpin memiliki jiwa melayani follower dengan ketulusan dan memberikan contoh OCB yang baik, maka hal ini dapat menumbuhkan OCB pula pada bawahannya. Perilaku OCB guru yang diperlukan untuk dapat mewujudkan tujuan organisasi sekolah antara lain untuk kesediaan menjalankan tugas-tugas di luar peran utama yang dimilikinya, kemauan untuk menjaga kepentingan organisasi, dan mengambil tanggung jawab yang lebih besar untuk memajukan organisasi.

\section{IMPLIKASI DAN KETERBATASAN}

\section{Implikasi Manajerial}

Bagi pengola organisasi pendidikan dan organisasi nonpendidikan, menciptakan iklim positif dan peningkatan kualitas kerja di lingkungan organisasi dapat diawali dengan mengintegrasikan lima peran kepemimpinan yang penting untuk kesuksesan pemimpin di organisasi yaitu: praktek kepemimpinan yang fokus pada pengembangan kharakter melalui sikap, nilai, dan kredibilitas diri; berorientasi pada pengembangan sumber daya manusia 
dan kualitas hubungan dengan bawahan; berorientasi pada tugas dengan menekankan pencapaian produktivitas dan keberhasilan; serta berorientasi pada peningkatan efisiensi organisasi melalui pengembangan sistem terbuka, efisien dan fleksibel.

\section{Keterbatasan Penelitian}

Meskipun temuan-temuan pada studi ini secara keseluruhan mendukung hipotesis yang diajukan, studi ini memiliki keterbatasan yang dapat diperbaiki pada studi berikutnya. Beberapa saran untuk pengembangan penelitian selanjutnya sebagai berikut:

1) Dalam penelitian ini employee engagement diukur dengan pendekatan dimensi tunggal, sehingga untuk pengukuran employee engagement dapat mengunakan pendekatan multi dimensi yaitu work engagement dan organization engagement. Alternatif lain dalam pengukuran employee engagement dapat mengacu pada referensi yang digunakan yaitu kriteria-kriteria dari DDI (Development Dimensions International) (Wellins Bernthal, Phelps 2005) dan NIST (National Institute of Standards and Technology) (Indonesia Quality Award 2011).

2) Untuk pengembangan hasil penelitian tentang konsekuensi positif praktek kepemimpinan yang efektif, dapat ditambahkan faktor komitmen organisasional dalam model penelitian baik untuk penelitian organisasi pendidikan maupun organisasi nonpendidikan.

\section{DAFTAR PUSTAKA}

Barbuto, J. E., Jr., \& Wheeler, D. W. 2006. Scale Development and Construct Clarification of Servant Leadership. Group \& Organization Management, Vol.31 (3), 300-326.

Baumruk, Ray dan Robert E. Gorman. (2006). Why Managers are Crucial to Increasing Engagement? Diunduh dari https://www.insala.com/employee-engagement/whymanagers-are-crucial-to-increasing-engagement.pdf, pada tanggal 3 Juni 2014.

Bhuono Agung Nugroho. 2005. Strategi Jitu Memilih Metode Statistik Penelitian dengan SPSS, Yogjakarta: Penerbit Andi.

Bies, Robert. J.2005. Are procedural justice and interactional justice conceptually distinct? In J. Greenberg \& J. Colquitt (Eds.), Handbook of organizational justice (pp. 85-112). Mahwah, NJ: Lawrence Erlbaum Associates.

Byrne, Zinta S. 2015. Perceptions of Organizational Justice, Identification, and Support Within Work Teams. Working Paper, Presented at the 18 th Annual Conferenceof the Society for Industrial and Organizational Psychology, Colorado, April 11-13, 2015, Diunduh dari http://www.colostate.edu.

Choi, Byoung Kwon, Hyoung Koo Moon, Wook Ko, Kyoung Min Kim. 2014. A Cross-Sectional Study of The Relationships Between Organizational Justices and OCB: Roles of Organizational Identification and Psychological Contracts. Leadership \& Organization Development Journal; Vol. 35 (6):530 - 554.

Coetzee, M. 2005. Organizational Justice. University of Pretoria etd. Diunduh dari http://upetd.up.ac.za/thesis/available/etd-04132005 130646/unrestricted/04chapter4.pdf. pada 27 November 2007. 
Cohen, Charash Y. \& P. E. Spector. 2001. The Role of Justice in Organizations: A meta analysis.Organizational Behavior and Human Decision Processes; Vol.86.

Colquitt, J. A., Conlon, D. E., Wesson, M. J., Porter, C. O., \& Ng, K. Y. 2001. Justice at the Millennium: A Meta-Analytic Review of 25 Years of Organizational Justice Research. Journal of Applied Psychology: Vol. 86: 425-445; didownload dari http://leeds faculty.colorado.edu/dahe7472/Colquitt\%202001.pdf; pada 2 Januari 2016.

Cropanzano, R., D. E. Bowen, and S. W. Gilliland. 2007.The Management of Organizational Justice. Academy of Management Perspectives, pp.:34-48.

DeConnick, James B. 2010. The Effect of Organizational Justice, Perceived Organizational Support, and Perceived Supervisor Support on Marketing Employees'Level of Trust. Journal of Business Research 63: 1349-1355.

Elamin, Abdallah M., Hayfaa A. Tlaiss. 2015.Exploring The Relationship Between Organizational Citizenship Behavior and Organizational Justice in the Islamic Saudi Arabian context. Employee Relations, Vol. 37 (1):2-29.

Fernandez, S., Cho, Y. J., \& Perry, J. L. 2010. Exploring The Link Between Integrated Leadership and Public Sector Performance. The Leadership Quarterly 21, 308 - 323.

Greenberg, Jerald dan Robert Baron. 2003. Behavior in Organizations (Understanding and Managing the Human Side of Work). Eight edition, Prentice Hall.

Huxham, C., \& Vangen, S. (2000). Leadership in the Shaping and Implementation of Collaboration Agendas: How Things Happen in a (not quite) Joined-up world. Academy of Management Journal, Vol.: 43(6), 1159-1175Li, Andrew and Russell Cropanzano. 2009. Do East Asians Respond More/Less Strongly to Organizational Justice Than North Americans? A Meta-Analysis. Journal of Management Studies; Vol.: 46 (5): 787-805.

Indonesian Quality Award Foundation (IQAF). 2011-2012. Kriteria Kinerja Ekselen Bidang Pendidikan. Yayasan Indonesian Quality Award. Jakarta.

Liden, Robert C., Sandy J. Wayne, Hao Zhao, and David Henderson.(2008). Servant Leadership: Development of Multidimensional Measure and Multi-Level Assesment. Leadership Quarterly, 19, 2 (April): 161-77.

Luthans, Fred. 2006. Perilaku Organisasi, Edisi Sepuluh, Yogyakarta: Penerbit Andi.

Mira, W. S. \& Margaretha, M. 2012. Pengaruh Servant Leadership Terhadap Komitmen Organisasi dan Organization Citizenship Behavior. Jurnal Manajemen, 11 (2): 99-116.

Mohammad, Jehad, Farzana Quoquab Habib and Mohmad Adnan Alias. 2011. Job Satisfaction and Organisational Citizenship Behavior: An Empirical Study At Higher Learning Institution. Jurnal Ilmu Pendidikan, (Online), Jilid 16, No. 2 diunduh dari http://web.usm.my/aamj/16.2.2011/AAMJ_16.2.7.pdf, pada 8 September 2015.

Organ, D.W., Podsakoff, P.M., \& MacKenzie, S.B. 2006. Organizational Citizenship Behavior: Its Nature, Antecedents, and Consequences. Sage, Beverly Hills, CA.

Page, D., \& Wong, T. P.2003. Servant leadership: An Opponent-Process Model and The Revised Servant Leadership Profile. Paper presented at the Servant Leadership Roundtable, Regent University, Virginia Beach, VA. Diunduh dari http://www.regent.edu/acad/cls/2003ServantLeadershipRoundtable pada tanggal 30 Juni 2014.

Rahayu, Susi A., dan Emma Surahman. 2012. Peran Kepemimpinan dan Employee Engagement terhadap Kinerja Individual Karyawan Instalasi Farmasi. Jurnal Farmasi Klinik Indonesia, Vol. 1 (3), September 2012.

Robbins, Stephen P, Timothy A. Judge 2008. Perilaku Organisasi, PT. Salemba Empat, Jakarta.

Saks, Alan M. 2006. Antecedents and Consequences of Employee Engagement. Journal of Managerial Psychology, Vol. 21 Iss: 7: $600-619$. 
Schaufeli, W.B., Salanova, M., Gonza'lez-Roma, V. \& Bakker, A. 2002. The Measurement of Engagement and Burnout: A Two Sample Confirmatory Factor Analytic Approach. Journal of Happiness Studies, 3: 71-92.

Simpson, Patricia A. dan Michelle Kaminski. 2007. Gender, Organizational Justice Perceptions, and Union Organizing. Employ Respons Rights J Vol. 19:57-72, diunduh dari http://www.law.harvard.edu/programs/lwp/WURF\%20Files/kaminski/simpson\%20and\%2 Okaminski.pdf, pada tanggal 5 Januari 2016.

Srimulyani, Veronika Agustini, dan Sri Rustiyaningsih. 2015. Kepemimpinan yang Melayani dan Pengaruhnya terhadap Kinerja Guru SMA dan SMK Swasta di Kota dan Kabupaten Madiun dengan Employee Engegament dan Perilaku Esktra-Peran sebagai Pemediasi. Simposium Nasional "The 8th NCFB and Doctoral Colloquium, Towards a New Indonesia Business Architecture, Fakultas Bisnis dan Pascasarjaan Unika Widya Mandala Surabaya 29-30 September 2015.

Vondey, M. 2010. The relationships among servant leadership, organizational citizenship behaviour, person-organization fit, and organizational identification. International Journal of Leadership Studies, 6(1), 3-27.

Yukl, G. A. 2002. Leadership in Organizations. Upper Saddle River, N.J: Prentice Hall.

Wellins, R. S., Bernthal, P., Phelps, M.2005. Employee Enggagement: The Key to Realizing Competitive advantage, DDI. 